DOI https://doi.org/10.18551/rjoas.2021-02.05

\title{
THE EFFECT OF FERTILIZATION MEDIA PH ON SPERMATOZOA FERTILIZATION PROCESS AS THE RESULTS OF SEXING ON PANGASIUS (PANGASIONODON HYPOPHTHALMUS)
}

\author{
Adhitomo Yudho*, Astuti Indri \\ Freshwater Aquaculture Center of Sungai Gelam, Ministry of Marine Affairs and Fisheries, \\ Jambi, Indonesia \\ Laishevtcev Alexey \\ Federal Scientific Center - All-Russian Research Institute of Experimental Veterinary \\ Medicine named after K.I. Skryabin and Y.R. Kovalenko of the Russian Academy \\ of Sciences, Moscow \& Laboratory of Biological Control and Antimicrobial Resistance, Orel \\ State University, named after I.S. Turgenev, Orel City, Russia \\ *E-mail: yudhoadhitomo02@gmail.com
}

\begin{abstract}
Pangasius ( $P$. hypophthalmus) is one of the freshwater commodities of an important economic value. The $\mathrm{pH}$ on fertilization media can influence fertilization and affect sex determination (Sandra and Norma, 2009). Sexing with Percoll Density Gradient Centrifugation (PDGC) method can separate $X$ and $Y$ spermatozoa based on their size (Rustidja, 1999). The study analyzed the results of $X$ and $Y$ spermatozoa sexing on Pangasius using the PDGC method and specified the ability of $\mathrm{pH}$ in influencing $\mathrm{X}$ and $\mathrm{Y}$ spermatozoa in the fertilization process. The results showed that, at stage 1 , the spermatozoa head on the top layer (La) was larger than that on the bottom layer. The spermatozoa head length $(\mathrm{HL})$ on the top layer was $2.59 \pm 0.19 \mu \mathrm{m}$ with a wide length $(\mathrm{WL})$ of $1.62 \pm 0.11 \mu \mathrm{m}$. Meanwhile, on the bottom layer, the HL was $2.27 \pm 0.12 \mu \mathrm{m}$ with a WL of $1.44 \pm 0.07 \mu \mathrm{m}$. Therefore, the top layer was identified as $X$ (female) and the bottom layer as $Y$ (male). The average value of spermatozoa concentration after PDGC at the top layer was $7.11 \pm 1.743 \times 10^{7}$ cells $/ \mathrm{mL}$ and at the bottom layer was $3.57 \pm 1.075 \times 10^{7}$ cells $/ \mathrm{mL}$. The average value of motility at the top layer was $61.67 \pm 7.637 \%$ and at the bottom layer was $46.67 \pm 5.773 \%$, and the average value of viability at the top layer was $61.04 \pm 7.27 \%$ and at the bottom layer was $55.17 \pm 2.53 \%$. This study revealed that the effect of $\mathrm{pH}$ on the fertilization rate (FR) with $\mathrm{Y}$ control spermatozoa was $-177.8+68.377 \mathrm{x}$ $4.234 \mathrm{x}^{2}, \mathrm{R}^{2}=0.603$. The finding confirmed that the best treatment for this control was $\mathrm{pH}$ 8.07 and FR $98.27 \%$. The assessment on $Y$ top layer spermatozoa resulted in of $-100.27+$ $40.836 x-2.568 x^{2}, R^{2} 0.637$. The finding showed that the best treatment for the top layer spermatozoa was pH 7.95 and FR $62.07 \%$. The examination on $\mathrm{Y}$ bottom layer spermatozoa generated an equation of $-32.195+22.746 x-1.4619 x^{2}, R^{2}=0.523$. It can be said that the best treatment in the bottom layer was $\mathrm{pH} 7.78$ and $\mathrm{FR} 56.28 \%$. However, the hatching rate $(\mathrm{HR})$ to $\mathrm{pH}$ treatment on each treatment did not show significant differences $(P>0.05)$. To sum up, the PDGC method on Pangasius spermatozoa could separate the spermatozoa based on the top and bottom layer size. The PDGC method could produce female seeds on the top layer by $85 \%$ and male seeds on the bottom layer by $68 \%$.
\end{abstract}

\section{KEY WORDS}

Fertilization, Pangasius, $\mathrm{pH}$, spermatozoa.

Pangasius (Pangasionodon hypophthalmus) is a freshwater commodity that has a significant economic value in Indonesia and other Asian countries (Legendre et al., 2008). A method that can produce specific sex from the early stage of rearing (larvae/seed) will create cost-efficiency in feed, ponds, and cultivation labor. 
Producing specific sex is crucial and is the main target in aquaculture either for commercial or efficiency purposes because it affects reproduction, growth, and product quality (Alyssa et al ., 2015). It has been noted that the growth rate of female Pangasius is $25-30 \%$ faster than the male Pangasius (both $P$. hypopthalmus and Pangasius djambal) (Arfah and Carman, 2008; Slembrouck et al., 2003). The results from a previous study pointed out that sex determination in teleost fish depends on genetic and environmental factors (Sandra and Norma, 2009). In this matter, genetic factors are influenced by Chromosomal Sex Determination/CSD (Alyssa et al., 2015).

Besides genetic factors, an environmental factor, the acid-base atmosphere $(\mathrm{pH})$ at the time of fertilization, also influences sex determination (Sandra and Norma, 2009). $X$ and $Y$ chromosomes have different characters (X chromosomes are resistant to acidic conditions, while $\mathrm{Y}$ chromosomes are more resistant to alkaline conditions). If the $\mathrm{pH}$ is acidic at the time of fertilization, the seeds will be dominated by males, and if the $\mathrm{pH}$ is alkaline, the seeds will be dominated by females. One of the techniques to produce such specific sex is known as sexing. Sexing is a method of separating $X$ and $Y$ spermatozoa (Susilawaty, 1994) done through Percoll Density Gradient Centrifugation (PDGC) (Kaneko et al., 1984). PDGC is performed to make a density gradient/media concentration and precipitate or separate the spermatozoa through a centrifuge. $X$ and $Y$ spermatozoa have different mass and size. Therefore, the $Y$ spermatozoa, which are smaller than the $X$ spermatozoa, can move faster since they have a higher penetration power to enter a solution. The $Y$ spermatozoa will move downwards, while the $X$ spermatozoa will stay on the top layer.

The objectives of this study are as follows:

- To know the sexing results of $X$ and $Y$ spermatozoa through the PDGC method on Pangasius ( $P$. hypophthalmus);

- To determine the ability of $\mathrm{pH}$ in affecting $\mathrm{X}$ and $\mathrm{Y}$ spermatozoa in the fertilization process.

\section{METHODS OF RESEARCH}

This study took place in February 2016 at the Laboratory of Fish Reproduction, Faculty of Fisheries and Marine Sciences, Universitas Brawijaya. The spermatozoa separation was done using the PDGC method at the Laboratory of Artificial Insemination Center, Singosari, as one of the Ministry of Agriculture work units. The observation of spermatozoa morphology was carried out at the Zoology-Biology Research Center, Indonesian Institute of Sciences (Lembaga IImu Pengetahuan Indonesia or LIPI) in Cibinong, Bogor. The fish seed gonads were observed at the Laboratory of Fish Health and Environment, Freshwater Aquaculture Center, Sungai Gelam, Jambi.

This study used Pangasius broodfish consisting of 6 females and 11 males from the National Pangasius Development Center (Pusat Pengembangan Induk Patin Nasional or PUSTINA), Freshwater Aquaculture Center, Sungai Gelam, Jambi, Ministry of Marine Affairs and Fisheries.

The hormone used in this study was ovaprim (Syndel Laboratories, Canada), a combination of domperidone and salmon gonadotropin-releasing hormone analog. $1 \mathrm{~mL}$ of ovaprim contains $0.02 \mathrm{mg}$ of salmon gonadotropin-releasing hormone analog and $10 \mathrm{mg}$ of domperidone (Subagja et al., 2003).

The fertilization media solution was set at a $\mathrm{pH}$ of $6,7,8,9$, and 10. A mixture of citric acid $\left(\mathrm{C}_{6} \mathrm{H}_{8} \mathrm{O}_{7}\right)$ with distilled water was made to create a $\mathrm{pH} 6$ solution. Whereas, $\mathrm{CaOH}$ was mixed with distilled water to make $\mathrm{pH} 8,9$, and 10 solutions.

The material used to separate spermatozoa through PDGC was tris aminomethane solution. It is a fresh semen diluent that functions as a living medium for spermatozoa because it contains nutrients and energy sources. The composition of tris aminomethaneegg yolk is tris aminomethane $1.363 \mathrm{~g}$, citric acid $0.762 \mathrm{~g}$, lactose $1.5 \mathrm{~g}$, raffinose $2.7 \mathrm{~g}$, fructose $0.5 \mathrm{~g}$, penicillin $0.1 \mathrm{~g}$, streptomycin $0.1 \mathrm{~g}$, egg yolk $20 \mathrm{~mL}$, and $\mathrm{NaCl} 0.9 \%$ as much as $80 \mathrm{~mL}$. Male Pangasius broodfish used in this study weighed $1.5-2 \mathrm{~kg} / \mathrm{fish}$ and aged $>1.5$ 
years. An excellent male broodfish will release white spermatozoa from its genital if it is slowly massaged. The spermatozoa obtained were used as material for further examination.

The spermatozoa were retrieved from 3 male Pangasius broodfish using a $1 \mathrm{~mL}$ syringe and then mixed and stirred slowly until homogeneous.

The separation of $X$ and $Y$ spermatozoa in this study was done using the PDGC method. According to Rustidja (1999), the PDGC method is used to create a density gradient/media concentration and to precipitate or separate spermatozoa using a centrifuge. There were 6 levels of Percoll Density Gradient taken in this study $(10 \%, 20 \%, 30 \%, 40 \%$, $50 \%$, and $60 \%$ ) centrifuged at a speed of $1500 \mathrm{rpm}$ for 15 minutes. The making of the Percoll media gradient was completed using tris aminomethane-egg yolk.

In this study, the female Pangasius broodfish had mature gonad and weighed 2 - 2.5 $\mathrm{kg} / \mathrm{fish}$ aged $>2$ years. The female broodfish to be spawned was selected for its gonad maturity by observing the diameter of the oocyte through biopsy/cannulation.

The hormone-injected dose was $2 \times 0.5 \mathrm{~mL} / \mathrm{kg}$ of fish weight (the first injection was $1 / 3$ of the dose, and the second injection was $2 / 3$ of the dose). The interval between the first injection and the second injection was 6 hours. Ovulation would occur 6 hours after the second injection depending on the temperature of the water (Baidya and Senoo, 2002). The hormone was injected at the right/left dorsal (intramuscular) with an injection angle of $45^{\circ}$. Stripping of the female Pangasius is a technique of removing eggs from the fish's stomach by gently massaging (by hand) the abdomen from the head to the genital opening. Before stripping, the fish were given an anesthetic to facilitate the handling and avoid stress on the fish.

Fish eggs were fertilized with top and bottom layers of spermatozoa that had passed PDGC and spermatozoa without Percoll/control (referring to the analysis results in Stage I) on different fertilization media $\mathrm{pH}(\mathrm{pH} 6,7,8,9$, and 10). The results were then analyzed further for the fertilization rate (FR) and the hatching rate $(\mathrm{HR})$.

The larvae and seeds were maintained separately on each treatment. The larvae were reared for 15 days and fed with Artemia nauplii 5 times a day (07:00 UTC+7, 11:00 UTC+7, 15:00 UTC+7, 19:00 UTC+7, and 23:00 UTC+7) from the $2^{\text {nd }}$ to $7^{\text {th }}$ day after hatching. After the $8^{\text {th }}$ day, the larvae would be fed with Tubifex sp. until the $15^{\text {th }}$ day. After that, the seeds were reared for 45 days and fed with worm seeds and Tubifex through an ad libitum manner. During this rearing, $50 \%$ of the water was removed. The water quality was maintained at $30^{\circ} \mathrm{C}$ with a $\mathrm{DO}$ of $>50 \mathrm{mg} / \mathrm{l}$ and $\mathrm{pH} 7$.

The comparison of male and female larvae was implemented using the acetocarmine squash method. The process was started with an acetocarmine solution that was 0.6 grams of carmine powder added with $100 \mathrm{~mL}$ of $45 \%$ acetic acid. Then, the mixture of carmine powder and acetic acid was heated for 2-4 minutes. After the mixture was cooled down, it was brought to be filtered to separate the coarse particles (Kurniasih et al., 2006). The observation of the sex ratio was carried out on Pangasisus seeds aged +45 days (D45). In this study, 10 samples were taken for each treatment. The stomach of those samples was dissected to get a gonad candidate. The prospective fish gonads were then compared with the whole samples to obtain the sex ratio of the seeds.

\section{RESULTS AND DISCUSSION}

In this study, the average body weight of male Pangasius was $1628 \mathrm{gr} / \mathrm{fish}$. This result was different from the research of Slembrouck (2000) that the bodyweight of male Pangasius broodfish (mature gonads) was $>2 \mathrm{~kg}$. Besides that, the average testicular weight of the fish was $74.93 \mathrm{gr}$. This genital weight analysis aimed to calculate the Testicular Somatic Index (TSI) value to describe the level of maturity of the male broodfish.

That would become the weight ratio of the testis/gonad to the total weight of fish. Jamieson and Barrie (2009) mentioned that the ratio of testicular weight/size to body weight was an important variable to determine the level of gamete cell maturity on male fish. In this study, the mean value of TSI was 4.74. The highest TSI value was found to be 7.45 at a bodyweight of 1.525 grams. It was revealed that a heavier bodyweight of 1.911 grams had 
the lowest TSI value of 2.98. The average total length and the standard length of male Pangasius broodfish were $53.33 \mathrm{~cm}$ and $44 \mathrm{~cm}$.

Table 1 - The Results of Male Pangasius Broodfish Spermatozoa Analysis

\begin{tabular}{lrrrr}
\hline & \multicolumn{3}{c}{ Broodfish } & \multicolumn{2}{c}{ Mean } \\
\cline { 2 - 4 } Parameter & \multicolumn{1}{c}{ A } & B & C & 1628.67 \\
Body Weight $(\mathrm{g})$ & 1450 & 1525 & 1911 & 74.93 \\
TSI (g) & 54.30 & 113.60 & 56.90 & 4.72 \\
Somatic Index (\%) & 3.74 & 7.45 & 2.98 & 53.33 \\
Total Length (cm) & 58 & 59 & 43 & 44.33 \\
Standard Length (cm) & 43 & 44 & 46 & \\
\hline
\end{tabular}

$3.34 \times 10^{9} \mathrm{cells} / \mathrm{mL}$ and the lowest was $3.17 \times 10^{9}$ cells $/ \mathrm{mL}$ with an average of $3.07 \pm$ $0.34 \times 10^{9} \mathrm{cells} / \mathrm{mL}$. In this study, the spermatozoa density value was directly proportional to the value of TSI and motility.

Table 2 - The Results of Male Pangasius Broodfish Spermatozoa Analysis

\begin{tabular}{|c|c|c|c|c|}
\hline \multirow{2}{*}{ Parameter } & \multicolumn{3}{|c|}{ Broodfish } & \multirow[t]{2}{*}{ Mean } \\
\hline & A & B & C & \\
\hline Density (cells $\times 10^{9}$ cells $/ \mathrm{mL}$ ) & 3.17 & 3.34 & 2.69 & $3.07+0.34$ \\
\hline Motility (\%) & 80.77 & 90.13 & 85.41 & $85.44+4.68$ \\
\hline $\mathrm{pH}$ & 7.6 & 7.2 & 7.4 & $7.40+0.20$ \\
\hline Viability (\%) & 78.7 & 85.43 & 80.12 & $81.42+3.54$ \\
\hline
\end{tabular}

The oocyte observation in this study was finished using sera solution and analysis of oocyte diameter distribution from 5 female Pangasius broodfish. The oocytes of broodfish number 3 were given the sera solution and showed no clot with an even diameter. The oocyte diameter's distribution pattern was between $0.80-1.00 \mathrm{~mm}$, meaning that $84.84 \%$ of the oocytes were in the state of final gonad maturation. From this result, the spawning could be predicted to succeed after it was administered with hormone by $60-80 \%$. Nevertheless, there were only $15.15 \%$ of the oocytes with a diameter between $0.55-0.75 \mathrm{~mm}$. To sum up, Pangasius number three, with a bodyweight of $4.60 \mathrm{~kg}$, was the best broodfish based on oocyte analysis.

The centrifugation results in this study could be seen on the clear white top layer $/ 1^{\text {st }}$ layer. The spermatozoa were obvious on the $2^{\text {nd }}$ to the $6^{\text {th }}$ layer and started to look clear on the $7^{\text {th }}$ layer.

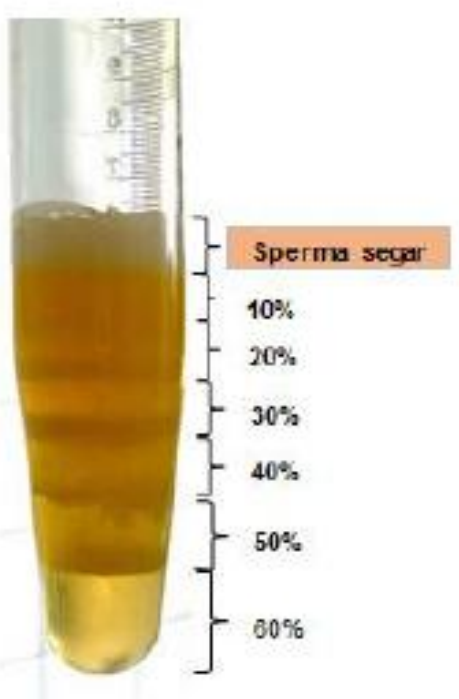

A

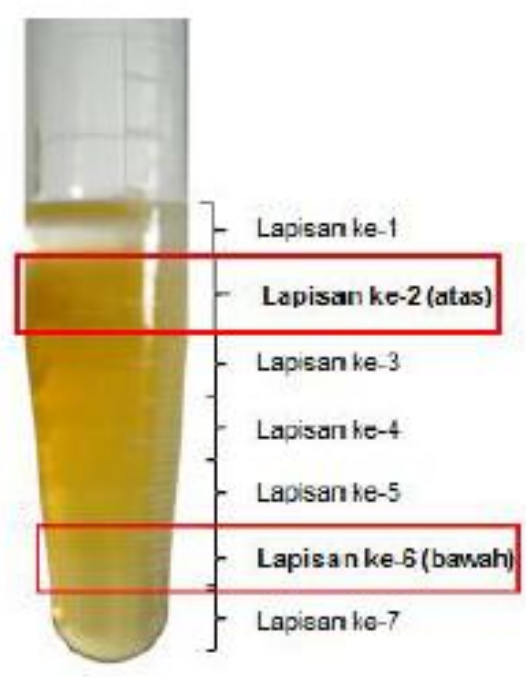

B

Figure 1 - Percoll density gradient A. Before centrifugation B. After centrifugation 
In this study, the morphometric analysis of Pangasius spermatozoa was carried out by measuring the length and width of the spermatozoa head, both from PDGC treatment and non-PDGC treatment, through "JEOL" JSM-5310LV Scanning Electron Microscope (SEM). The digital data from SEM were further processed using image-J digital data processing software version 1.44 to analyze the size distribution of the spermatozoa.

Table 3 - The Results of Spermatozoa Size Analysis After Centrifugation without PDGC

\begin{tabular}{|ccc|}
\hline Layer & Length $(\mu \mathrm{m})$ & Width $(\mu \mathrm{m})$ \\
\hline $1^{\text {st }}$ & $2.53 \pm 0.21$ & $1.61 \pm 0.13$ \\
\hline $2^{\text {nd }}($ Top $)$ & $2.59 \pm 0.17$ & $1.65 \pm 0.14$ \\
\hline $3^{\text {rd }}$ & $2.49 \pm 0.19$ & $1.57 \pm 0.10$ \\
$4^{\text {th }}$ & $2.52 \pm 0.17$ & $1.58 \pm 0.11$ \\
$5^{\text {th }}$ & $2.54 \pm 0.21$ & $1.59 \pm 0.11$ \\
\hline $6^{\text {th }}($ Bottom $)$ & $2.51 \pm 0.18$ & $1.59 \pm 0.11$ \\
\hline $7^{\text {th }}$ & $2.56 \pm 0.21$ & $1.64 \pm 0.13$ \\
\hline
\end{tabular}

The results of spermatozoa head size analysis after centrifugation without PDGC pointed out that the length of the top layer was $2.59 \pm 0.17 \mu \mathrm{m}$ with a width of $1.65 \pm 0.14$ $\mu \mathrm{m}$. Meanwhile, the length of the bottom layer was $2.51 . \pm 0.18 \mu \mathrm{m}$ with a width of $1.59 \pm$ $0.11 \mu \mathrm{m}$.

Table 4 - The Results of Spermatozoa Size Analysis after Centrifugation with PDGC

\begin{tabular}{|ccc|}
\hline Layer & Length $(\mu \mathrm{m})$ & Width $(\mu \mathrm{m})$ \\
\hline $1^{\text {st }}$ & $2.56 \pm 0.14$ & $1.58 \pm 0.10$ \\
\hline $2^{\text {nd }}($ Top $)$ & $2.59 \pm 0.19$ & $1.62 \pm 0.11$ \\
\hline $3^{\text {rd }}$ & $2.75 \pm 0.21$ & $1.73 \pm 0.13$ \\
$4^{\text {th }}$ & $2.50 \pm 0.13$ & $1.58 \pm 0.09$ \\
$5^{\text {th }}$ & $2.53 \pm 0.19$ & $1.56 \pm 0.10$ \\
\hline $6^{\text {th }}($ Bottom $)$ & $2.27 \pm 0.12$ & $1.44 \pm 0.07$ \\
\hline $7^{\text {th }}$ & nd & Nd \\
\hline
\end{tabular}

*nd: spermatozoa not found.

Table 4 above depict that the length of the top layer is $2.59 \pm 0.19 \mu \mathrm{m}$ with a width of $1.62 \pm 0.11 \mu \mathrm{m}$ while the length of the bottom layer is $2.27 \pm 0.12 \mu \mathrm{m}$ with a width of $1.44 \pm$ $0.07 \mu \mathrm{m}$.

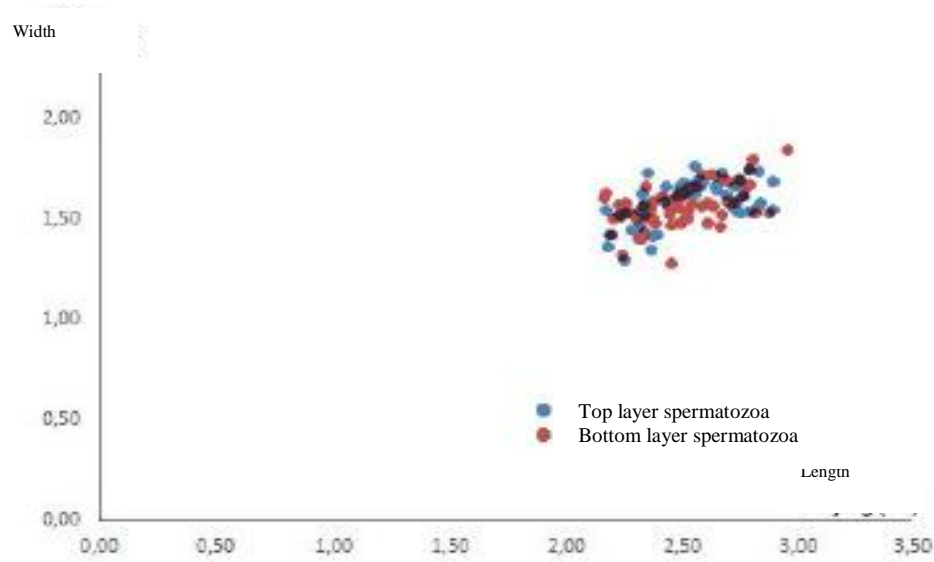

Figure 2 - Distribution of the spermatozoa head size between the top and bottom layer without PDGC

Figure 2 depicts no significant difference in the distribution pattern between the size of the top and lower layer spermatozoa. On the other hand, the post-PDGC treatment results (Figure 3) below show a highly significant difference. The mean value of spermatozoa concentration in control spermatozoa was $7.34 \pm \times 10^{8}$ cells $/ \mathrm{mL}$ and decreased in the top 
layer by $10.32 \%$ with a value of $7.11 \times 10^{7} \mathrm{cells} / \mathrm{mL}$. As for the bottom layer, the spermatozoa concentration was $3.57 \times 10^{7}$ cells $/ \mathrm{mL}$.

In this study, the control spermatozoa had the highest viability of $70.27 \pm 5.87 \%$. The viability value of the top layer spermatozoa was $61.04 \pm 7.27 \%$. That was higher than the bottom layer spermatozoa, which had a value of $55.17 \pm 2.53 \%$.

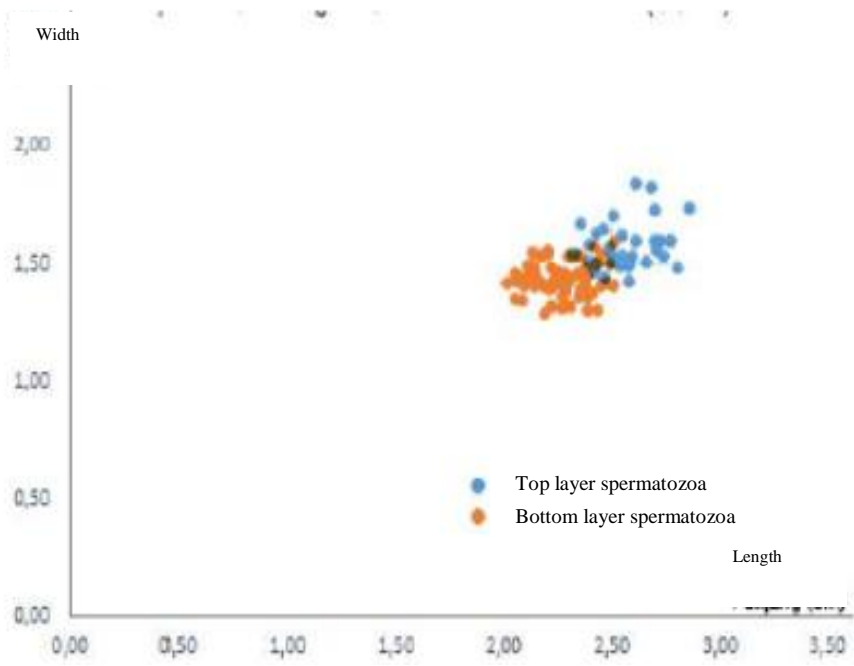

Figure 3 - Distribution of the spermatozoa head size between the top and bottom layer after PDGC

Table 5 - Spermatozoa Concentration after PDGC

\begin{tabular}{cl}
\hline Treatment & Mean \pm Std. Dev. \\
\hline Control & $7.34 \pm 0.144 \times 10^{8}$ \\
Top Layer & $7.11 \pm 1.743 \times 10^{7}$ \\
Bottom Layer & $3.57 \pm 1.075 \times 10^{7}$ \\
\hline
\end{tabular}

The average value of motility in the top layer was $62.67 \pm 7.63 \%$, while the bottom layer was $46.67 \pm 5.77 \%$.

Table 6 - Spermatozoa Motility after PDGC

\begin{tabular}{cc}
\hline Treatment & Mean \pm Std. Dev. (\%) \\
\hline Control & $88.33 \pm 2.88$ \\
Top Layer & $61.67 \pm 7.63$ \\
Bottom Layer & $46.67 \pm 5.77$ \\
\hline
\end{tabular}

Table 7 - Spermatozoa Viability after PDGC

\begin{tabular}{cc}
\hline Treatment & Mean \pm Std. Dev. (\%) \\
\hline Control & $70.26 \pm 5.87$ \\
Top Layer & $61.67 \pm 7.27$ \\
Bottom Layer & $55.17 \pm 2.53$ \\
\hline
\end{tabular}

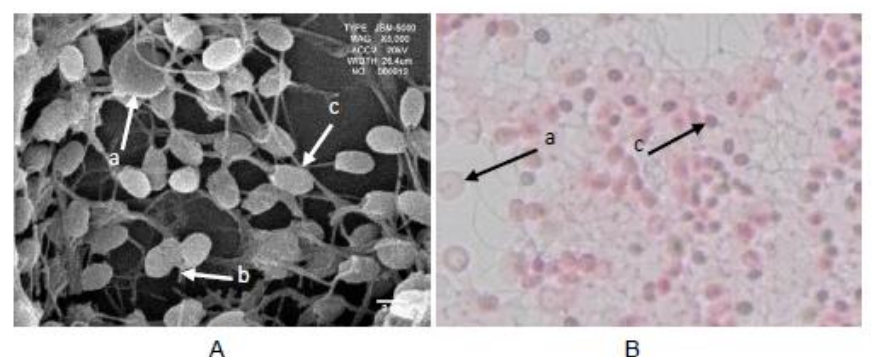

Figure 4 - The results of damage analysis of Pangasius spermatozoa A. Observation of damage on spermatozoa using SEM with 5000x enlargement. a: The damage of the head membrane.

b: The damage of the broken tail. B. Observation of damage on spermatozoa with acetocarmine. c: Living/motile spermatozoa. 
The effect of $\mathrm{pH}$ on the fertilization rate of Pangasius eggs on control spermatozoa and post-PDGC spermatozoa treatment in the top and bottom layers is presented in Table 8 below:

Table 8 - Fertilization Rate of Pangasius Eggs on Control Spermatozoa and post-PDGC Spermatozoa

\begin{tabular}{cccc}
\hline Treatment & & Spermatozoa & \\
\cline { 2 - 4 } & Control & Top Layer & Bottom Layer \\
\hline pH 6 & $81.21 \pm 9.72^{\mathrm{a}}$ & $52.59 \pm 1.28^{\mathrm{a}}$ & $51.92 \pm 1.68^{\mathrm{a}}$ \\
$\mathrm{pH} \mathrm{7}$ & $90.78 \pm 0.72^{\mathrm{a}}$ & $58.60 \pm 2.88^{\mathrm{a}}$ & $54.11 \pm 1.86^{\mathrm{a}}$ \\
$\mathrm{pH} \mathrm{8}$ & $98.99 \pm 1.74^{\mathrm{c}}$ & $63.76 \pm 7.12^{\mathrm{c}}$ & $58.46 \pm 3.14^{\mathrm{b}}$ \\
$\mathrm{pH} \mathrm{9}$ & $96.24 \pm 3.26^{\mathrm{b}}$ & $58.13 \pm 2.72^{\mathrm{b}}$ & $52.39 \pm 2.12^{\mathrm{a}}$ \\
pH 10 & $81.65 \pm 11.15^{\mathrm{a}}$ & $51.56 \pm 1.67^{\mathrm{a}}$ & $49.55 \pm 3.32^{\mathrm{a}}$ \\
\hline
\end{tabular}

$\mathrm{pH}$ dramatically affects the fertilization rate of Pangasius eggs because it is very influential in regulating spermatozoa motility. It is known that intracellular $\mathrm{pH}$ signals pathways in various spermatozoa cell activities. Meanwhile, extracellular $\mathrm{pH}$ affects intracellular $\mathrm{pH}$, thereby interfering with spermatozoa activity in the ability to fertilize eggs. The effect of extracellular $\mathrm{pH}$ can increase the $\mathrm{H}+$ ions of intracellular $\mathrm{pH}$ to bother ATP metabolic enzyme activity. The inhibition of $\mathrm{HCO} 3-$ and $\mathrm{Ca}+$ influx is essential in regulating spermatozoa motility. Acidic $\mathrm{pH}$ will interrupt the intracellular metabolism, which indirectly inhibits ATP production in spermatozoa cells and the signaling pathway of spermatozoa motility. A pH that is too extreme can cause protein denaturation and thus damaging spermatozoa cells. An alkaline $\mathrm{pH}$ will trigger spermatozoa motility because HCO3- is needed in the signaling pathway of spermatozoa motility. HCO3- can activate CAMP in activating spermatozoa motility, but extreme $\mathrm{pH}$ will certainly inhibit spermatozoa motility.

Based on orthogonal polynomial analysis of control spermatozoa (Figure 5), a quadratic curve was obtained with the equation of $y=-177.8+68.377 x-4.234 x^{2}$ with an $\mathrm{R}^{2}=0.6034$. From this equation, the best treatment is obtained at $\mathrm{pH} 8.07$ and a fertilization rate of $98.27 \%$.

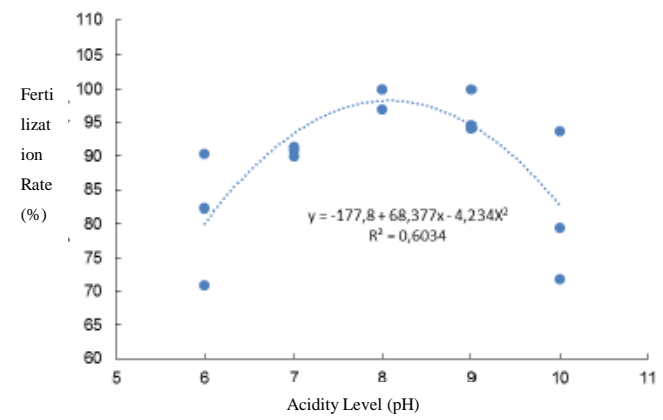

Figure 5 - Graph of the relationship between $\mathrm{pH}$ and fertilization rate of Pangasius eggs in control spermatozoa

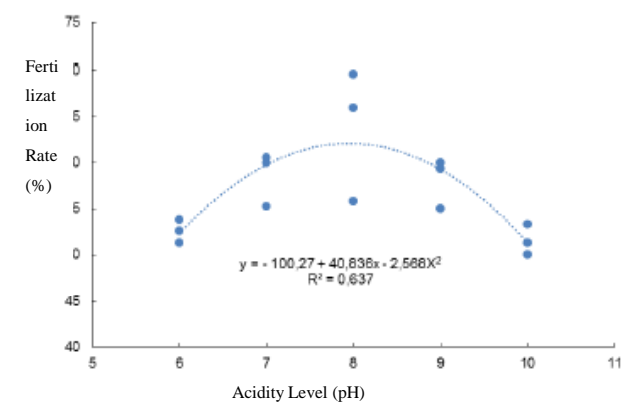

Figure 6 - Graph of the relationship between $\mathrm{pH}$ and fertilization rate of Pangasius eggs in the top layer spermatozoa 
In the top layer of centrifuged spermatozoa (Figure 6), it is displayed a quadratic curve with the equation $y=-100.27+40.836 x-2.568 x^{2}$ with an $R^{2}=0.637$. The results pointed out that the best treatment was obtained at pH 7.95 and an $\mathrm{FR}$ of $62.07 \%$.

Seen in the bottom layer of spermatozoa (Figure 7), a quadratic curve is obtained with the equation $y=-32.195+22.746 x-1.4619 x^{2}$ with an $R^{2}=0.523$.

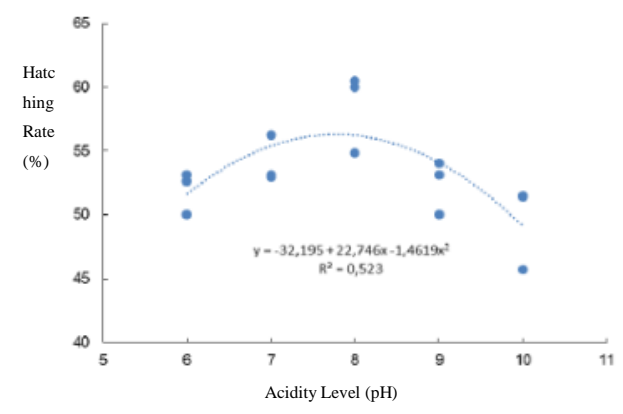

Figure 7 - The relationship between $\mathrm{pH}$ and fertilization rate of Pangasius eggs in bottom layer spermatozoa

The best treatment in this layer is $\mathrm{pH} 7.78$ and an $\mathrm{FR}$ of $56.28 \%$.

This study showed that the hatching rate of Pangasius eggs on each $\mathrm{pH}$ treatment did not have a significant difference $(P>0.05)$.

Table 9 - Hatching Rate of Control Spermatozoa and post-PDGC Spermatozoa

\begin{tabular}{cccc}
\hline Treatment & & Spermatozoa & \\
\cline { 2 - 4 } & Control & Top Layer & Bottom Layer \\
\hline pH 6 & $31.31 \pm 1.64^{\text {ns }}$ & $28.67 \pm 1.28^{\mathrm{a}}$ & $51.92 \pm 1.68^{\mathrm{a}}$ \\
pH 7 & $44.39 \pm 16.71^{\mathrm{ns}}$ & $30.58 \pm 2.88^{\mathrm{a}}$ & $54.11 \pm 1.86^{\mathrm{a}}$ \\
$\mathrm{pH} 8$ & $47.75 \pm 15.13^{\mathrm{ns}}$ & $63.76 \pm 7.12^{\mathrm{c}}$ & $58.46 \pm 3.14^{\mathrm{b}}$ \\
$\mathrm{pH} \mathrm{9}$ & $34.77 \pm 16.34^{\mathrm{ns}}$ & $58.13 \pm 2.72^{\mathrm{b}}$ & $52.39 \pm 2.12^{\mathrm{a}}$ \\
$\mathrm{pH} \mathrm{10}$ & $29.14 \pm 8.49^{\mathrm{ns}}$ & $51.56 \pm 1.67^{\mathrm{a}}$ & $49.55 \pm 3.32^{\mathrm{a}}$ \\
\hline
\end{tabular}

The PDGC method on Pangasius spermatozoa can separate spermatozoa based on the size in the top and bottom layers. This study discovered that female seeds dominate the top layer by $85 \%$, while male seeds dominate the bottom layer by $68 \%$.

Table 10 - Prospective Gonad Observation

\begin{tabular}{ccc}
\hline Treatment & Female Ratio (\%) & Male Ratio (\%) \\
\hline Control & $59 \pm 9.90$ & $41 \pm 9.90$ \\
Top Layer & $85 \pm 7.07$ & $21 \pm 12.73$ \\
Bottom Layer & $32 \pm 11.31$ & $68 \pm 11.31$ \\
\hline
\end{tabular}

\section{CONCLUSION AND SUGGESTIONS}

Findings confirmed that the Percoll Density Gradient Centrifugation (PDGC) method successfully separated the Pangasius spermatozoa based on the head size. The top layer spermatozoa $(P=2.59 \pm 0.17 \mu \mathrm{m}$ and $L=1.62 \pm 0.14 \mu \mathrm{m})$ was larger than the bottom layer spermatozoa $(P=2.51 \pm 0.18 \mu \mathrm{m}$ and $\mathrm{L}=1.59 \pm 0.11 \mu \mathrm{m})$. PDGC method could influence the concentration, motility, viability, fertilization rate, and hatching rate of top and bottom layer spermatozoa and the sex ratio of the seeds produced. Findings proved that the possibility to produce female seeds was larger in the top layer treatment (85\%). In contrast, male seeds were found to dominate the bottom layer treatment by $68 \%$.

The effect of fertilization media $\mathrm{pH}$ on the fertilization rate with control spermatozoa was described in the equation $y=-177.8+68.377 x-4.234 x^{2}$ with an $R^{2}=0.6034$. As a result, the best treatment, in this case, was pH 8.07 with an FR of $98.27 \%$. In the top layer of spermatozoa, an equation of $y=-100.27+40.836 x-2.568 x^{2}$ with an $R^{2}=0.637$ was 
obtained. The findings implied that the best treatment for top layer spermatozoa was $\mathrm{pH}$ 7.95 , with an FR of $62.07 \%$. On the other hand, the equation for bottom layer spermatozoa was found to be $y=-32.195+22.746 x-1.4619 x^{2}$ with an $R^{2}=0,523$. Thus, $p H 7.78$ and an FR of $56.28 \%$ were the best treatments for bottom layer spermatozoa.

Further studies are suggested to examine this Pangasius cultivation on production scale/mass scale to determine its field performance tests. It is also recommended to explore the specific protein content in $X$ and $Y$ spermatozoa as biomarkers more deeply. Based on the effect of $\mathrm{pH}$ on Pangasius eggs' fertilization, the optimum $\mathrm{pH}$ for fertilization is at $\mathrm{pH} 8$. Pangasius cultivation centers are advised to find a location with a water source with a $\mathrm{pH}$ range of 8 , or as an alternative, the water can be treated first with specific techniques to obtain $\mathrm{pH}$ 8. This study explains that the success of a fertilization process is determined by the spermatozoa quality and the optimum $\mathrm{pH}$ of the fertilization media, and the quality of eggs from broodfish ready to spawn. In this study, the failures occurred several times during the fertilization process because the broodfish were not ready to spawn, so it is advisable to pay attention to the maturity of the gonads by analyzing the oocytes.

\section{REFERENCES}

1. Alyssa M. Budd, Quyen Q. Banh, Jose A. Domingos and Dean R Jerry. 2015. Sex Control in Fish: Approaches, Challenges, and Opportunities for Aquaculture. J. Mar. Sci. Eng. 3, pp 329-355.

2. Amersham. 2007. Percoll methodology and application. Handbook from Amersham Biosciences. pp 84.

3. Arfah, H dan Carman, O. 2008. Manipulasi Hormon dan suhu untuk produksi jantan homogamik $(\mathrm{XX})$ dalam rangka pengembangan budidaya monosex betina ikan patin siam (Pangasionodon hypopthalmus). Jurnal Akuakultur Indonesia, 7(1): pp 33-38.

4. Faradilah M A. 2015. Stratifikasi sel gamet jantan ikan tawes (Puntius javanicus) dalam rangka pendugaan jantan dan betina larva.

5. Hamid M. A, Wibowo W B, Irwan, Purba Y R, Lubis R A, Setiowibowo C, Furusawa A., 2015. Manual pembenihan patin siam (Pangasionodon hypophthalmus). Balai perikanan budidaya air tawar Sungai Gelam, Direktorat Jenderal Perikanaan Budidaya, Kementerian Kelautan dan Perikanan. hlm 1-40.

6. Kaneko S, Oshio S, Kobanawa K et al. 1984. Human X-and Y-bearing sperm differ in cell surface sialic acid content. Biochemical and Biophysical Research Communications 14, pp 950-955.

7. Legendre et al. 2008. Sperm characteristics and motility in Pangasionodon hypophthalmus (Sauvage,1878) and Pangasius djambal Bleeker, 1846 (Pangasiidae, Siluriformes). Cybium, 32(2) suppl.: pp 183-184.

8. Rustidja. 1999. Pemisahan spermatozoa X dan $Y$ ikan mas (Cyprinus carpio L) Fakultas Perikanan dan IImu Kelautan. Universitas Brawijaya. Malang. pp. 1-76.

9. Sandra and Norma. 2009. Sexual determination and differentiation in teleost fish. Rev Fish Biol Fisheries 20: pp 101-121.

10. Subagja, J. 2003. Rasio spermatozoa dengan telur pada pembuahan buatan Pangasius djambal (Pangasiidae) setelah di suntik dengan gonadotropin releasing hormon-analog (GnRH-a) dan domperidon. Jurnal Akuakultur Indonesia, 2(2): pp. 55-59.

11. Susilawati T. 2000. Analisis membran spermatozoa sapi hasil filtrasi sephandex dan sentrifugasi gradient densitas percoll pada proses seleksi jenis kelamin. Surabaya, universitas Airlangga. pp. 67-72. 